\title{
Clinical, demographical features, accompanying diseases and neutrophil to lymphocyte ratio- platelet to lymphocyte ratio in patients with bullous pemphigoid.
}

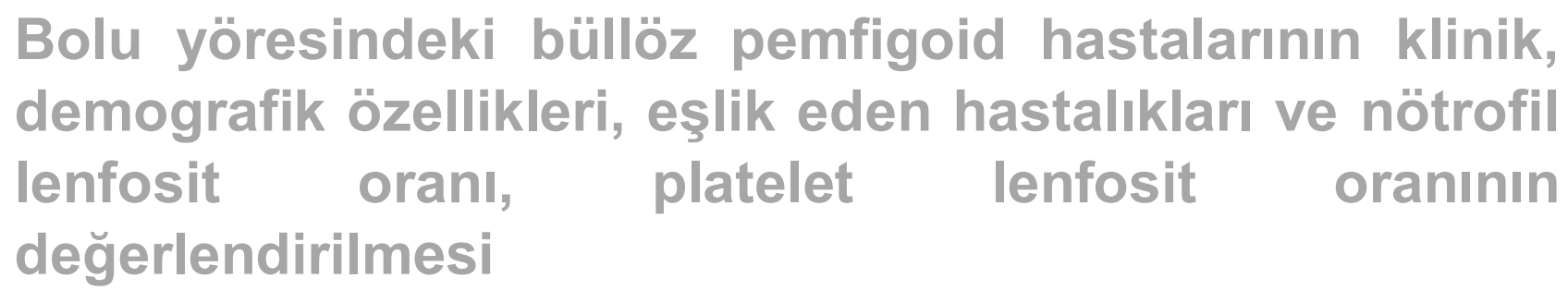

Betul Sereflican, Ali Haydlar Parlak

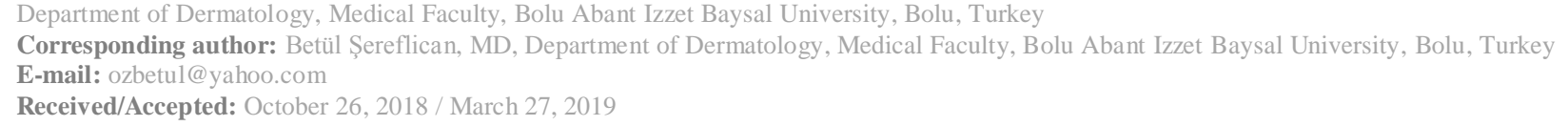

\section{SUMMARY}

Objective: Bullous pemphigoid (BP) is a rare autoimmune blistering disorder that affects the elderly population. In this study, we retrospectively evaluated the clinical, demographic characteristics and comorbid diseases in patients with BP. Mean platelet volume (MPV), neutrophil to lymphocyte ratio (NLR) and platelet to lymphocyte ratio (PLR) are known to be the indicators of inflammation. We also investigated MPV, NLR, and PLR values in patients with BP and a control group. To our knowledge, there is no previous study in the literature researching NLR, PLR and MPV together in patients with BP.

Method: A total of fourteen patients with BP and fourteen control subjects were included in the study. Medical reports of the patients who received clinical and histopathological diagnosis of BP between 2008 and 2018 were reviewed. MPV, NLR, and PLR values were recorded in BP patients and the control group.

Results: Of the 14 patients, 9 were female and 5 male. The most frequent comorbid chronic disease was hypertension, which was detected in $7(50 \%)$ patients. Four of the 7 patients with hypertension had coronary artery disease $(28,5 \%)$ at the same time. The NLR of patients with BP was significantly higher than that of the control group $(p=0.01)$. There was no difference in PLR and MPV between the groups.

Conclusions: The most common comorbidity in patients with BP in our study was cardiovascular diseases. More studies are needed to investigate the association between BP and cardiovascular disorders. In addition, NLR may be an inexpensive and simple parameter of inflammation in patients with BP and needs to be developed further.

Keywords: Bullous pemphigoid, neutrophil to lymphocyte ratio, platelet to lymphocyte ratio.

\section{ÖZET}

Amaç: Büllöz pemfigoid (BP) genellikle yaşlı hastalarda görülen, nadir rastlanan bir otoimmün büllöz hastalıktır. Bu çalışmada BP'li hastalarda klinik, demografik özellikler ve eşlik eden hastalıklar retrospektif olarak değerlendirildi. Ortalama trombosit hacmi (OTH), nötrofil lenfosit oranı (NLO) ve trombosit lenfosit oranının (TLO) inflamasyon göstergeleri olduğu bilinmektedir. Bu çalışmada ayrıca BP ve kontrol grubundaki hastalarda OTH, NLO ve TLO değerleri incelendi. Bildiğimiz kadarıyla OTH, NLO, TLO değerlerinin tümünü büllöz pemfigoidli hastalarda inceleyen bir çalışma literatürde yer almamaktadır.

Yöntem: Çalışmaya ondört BP hastası ve ondört kontrol grubu alındı. 2008-2018 yılları arasında klinik ve histopatolojik olarak BP tanısı alan hastaların kayıtları gözden geçirildi. BP hastalarında ve kontrol grubunda OTH, NLO ve TLO değerleri kaydedildi. 
Bulgular: Ondört hastanın dokuzu kadın beşi erkekti. En sık eşlik eden hastalık 7 (\% 50) hastada tespit edilen hipertansiyondu. Hipertansiyonu olan 7 hastanın $4(\% 28,5)$ 'ünde aynı zamanda koroner arter hastalığı eşlik etmekteydi. BP'li hastaların NLO'su kontrol grubundan anlamlı derecede yüksekti $(\mathrm{p}=0.01)$. Gruplar arasında TLO ve OTH değerleri açısından anlamlı fark yoktu.

Sonuç: Çalışmamızda BP'li hastalara en sık eşlik eden kardiyovasküler hastalıklardı. BP ve kardiyovasküler hastalıklar arasındaki ilişkiyi araştırmak için daha fazla sayıda çalışmaya ihtiyaç vardır. Ayrıca, NLO, BP hastalarında kullanılabilecek ucuz ve basit bir inflamasyon parametresi olabilir, bu yöndeki çalışmalar genişletilmelidir.

Anahtar sözcükler: Büllöz pemfigoid, nötrofil lenfosit oranı, trombosit lenfosit oranı

\section{INTRODUCTION}

Bullous pemphigoid (BP) is an autoimmune subepidermal blistering disease. ${ }^{1}$ In patients with BP, autoantibodies occur against the hemidesmosomal BP230 and BP180 glycoprotein in the basal membrane. It is characterized by pruritic urticarial plaques and tense bullae localized to the trunk and flexural areas of the extremities. ${ }^{2,3}$ Bullous pemphigoid mostly affects elderly people and rarely occurs in people younger than 50 years of age. ${ }^{4}$ Patients with BP represent an elevated expression of various cytokines and eosinophil activation resulting an inflammatory process. ${ }^{5}$ Recently an association between $\mathrm{BP}$ and neurological disorders have been reported. ${ }^{4}$ Also, there has been speculation of a potential thrombotic risk in BP patients. ${ }^{5}$

Mean platelet volume (MPV) correlates with platelet activation and it has been demonstrated that MPV is associated with inflammation. Therefore, it has been identified as a risk factor for for athero-thrombotic diseases. ${ }^{6,7}$ Neutrophil to lymphocyte ratio (NLR) and platelet to lymphocyte ratio (PLR) are the other systemic inflammation indicators that are used in state of chronic inflammatory diseases, including psoriasis. ${ }^{8}$ In one study that researches MPV, it was shown that MPV values were significantly higher in the patient group compared to healthy control. In another study, NLR values were significantly higher in the patient group compared to the healthy controls. ${ }^{9,10}$

In this study, our aim was to evaluate the clinical, demographic characteristics, comorbid diseases and MPV, NLR, PLR values in patients with BP.

To our knowledge, there is no previous study in the literature researching NLR, PLR and MPV together in patients with BP.

\section{MATERIAL AND METHODS}

Patients who received clinical and histopathological diagnosis of BP in Bolu Izzet Baysal Medical Faculty Dermatology Outpatient Clinic between 2008 and 2018 and age- and gender- matched control patients that were diagnosed with non-inflammatory dermatosis in the same clinic were enrolled into the study. We retrospectively screened the files of the subjects whom followed up for BP and controls in our clinic. Patients, whose clinic results were compatible but histopathology as incompatible with BP, were not be included in the study. The complete blood tests of the patients with BP were evaluated before the treatment period. Full blood counts for lymphocytes, neutrophils, platelets, NLR, PLR and MPV were recorded. The institutional ethics committee approved the study protocol with a reference number 2018/165.

SPSS software was used for conduction of statistical analyses. SPSS was used for statistical analysis. Numbers and percentages used for descriptive statistics and for categorical variables and presented as mean, standard deviation, median, 25th percentile, 75th percentile, and minimum and maximum. Two-Sample Kolmogorov-Smirnov Test used for comparison of nonhomogenous parameters and t-test for homogenous variables. The chi-square test used for categorical variables. Statistical significance level set on a $\mathrm{p}$ value lower than 0.05 .

\section{RESULTS}

Fourteen patients with BP (9 female, 5 male) and 14 control patients ( 9 female, 5 male) were included in the study. The mean age of the patient group and control group was $72 \pm$ 15 years. There was no significant difference between the two groups in terms of gender and age ( $\mathrm{p}=1, \mathrm{p}=0.98$; respectively).

Oral mucosal involvement was present in one of the cases $(7,1 \%)$. Dermatologic examination revealed excoriations and erosions in nine patients $(64,2 \%)$ and intact bullous lesions in five patients $(35,7 \%)$.

In the patient group; seven patients were diagnosed with hypertension (50\%), and four of these patients had coronary artery disease $(28,5 \%)$ at the same time; five patient had diabetes mellitus $(35,7 \%)$, one patient had cerebrovascular disease $(7,1 \%)$, one patient had chronic obstructive pulmonary disease 
(7.14\%), one had schizophrenia $(7,14 \%)$, one had depression $(7,1 \%)$, one had asthma $(7,1 \%)$, one had hyperthyroidism $(7.1 \%)$ and one had cholelithiasis $(7,1 \%)$.

Neutrophil counts were significantly higher in BP patients than the control group $(\mathrm{p}=0.01)$. Lymphocyte counts were significantly lower in BP patients than the control group $(\mathrm{p}=0.042)$. The NLR of patients with BP was significantly higher than that of the control group $(\mathrm{p}=0.01)$. There was no difference in platelet counts and PLR between the groups ( $\mathrm{p}=0.91, \mathrm{p}=0.06$, respectively). There was no difference in MPV between groups $(\mathrm{p}=0.6)$. (Table 1)

Table 1: Laboratory Parameters in Patients and Control Groups

\begin{tabular}{|l|l|l|l|}
\hline & Patient group (n=14) & Control group (n=14) & $\boldsymbol{p}$ \\
\hline Lymphocyte(K/uL) & $1,46 \pm 0.5$ & $2.08 \pm 0.95$ & $\mathbf{0 . 0 4 2}$ \\
\hline MPV (fL) & $7.9 \pm 1.02$ & $8.1 \pm 1.01$ & 0.6 \\
\hline Neutrophil (K/uL) & $4.3(1.5-9.6)$ & $1.9(0.8-4.6)$ & $\mathbf{0 . 0 1}$ \\
\hline Platelet (K/uL) & $237(178-388)$ & $216(136-285)$ & 0.91 \\
\hline NLR & $4.3(1.5-9.6)$ & $1.9((0.8-4.6)$ & $\mathbf{0 . 0 1}$ \\
\hline PLR & $154(83-407)$ & $103(65-464)$ & 0.06 \\
\hline
\end{tabular}

NLR: neutrophil/lymphocyte ratio; PLR: platelet/ lymphocyte ratio; MPV: Mean platelet volume

\section{DISCUSSION}

Bullous pemphigoid is an acquired bullous autoimmune dermatosis with an approximate annual incidence of 6 to 14 cases per 1 million population. It is primarily a disease of the geriatric population. ${ }^{11}$ In accordance with this data, our patients' mean age was $72 \pm 15$ years. In $10-30 \%$ of the bullous pemphigoid cases, there is an involvement of the oral mucosa. (11). In the studies of Akay et al. ${ }^{3}$, Ekiz et al. ${ }^{12}$ and Yazic1 et al. ${ }^{13}, 12,9 \%,, 17.2 \%$ and $28 \%$ of the patients had oral involvement, respectively. In our study the frequency of oral mucosal involvement $(7.1 \%)$ is lower compared to the literature. This result may be related to the mild course of the clinical lesions of our cases.

In our study, the most common comorbid diseases in patients with BP were hypertension (50\%), diabetes mellitus
(35.7\%) and coronary artery disease $(28.5 \%)$, respectively. In the study of Tan et al. ${ }^{14}$, the frequency of hypertension in BP patients was $55 \%$, diabetes mellitus was $32 \%$, and ischemic heart disease was $33 \%$. These frequencies were similar to our study. The most common comorbid diseases in the study of Kizilyel et al. ${ }^{15}$ were diabetes mellitus $(\% 7,9)$, hypertension $(\% 7,9)$ and peptic ulcer $(\% 7,9)$. In the study of Ekiz et al. ${ }^{12}$, BP was accompanied by diabetes $(17,24 \%)$, vitiligo $(3,4 \%)$, inflammatory bowel disease $(3,4 \%)$ and coronary artery disease $(3,4 \%)$. The high frequency of associated cardiovascular disease in our study may be due to the increased hypercoagulability in patients with BP. ${ }^{5}$

The relationship between BP and malignancy is controversial and an English national record linkage study found no increased risk for malignant cancers in a cohort of people 
with a diagnosis of BP. ${ }^{16}$ In our study, none of the patients had malignancy.

Autoreactive $\mathrm{T}$ cells play a critical role in the regulation of autoantibody production in BP. ${ }^{17}$ Histopathological studies show that eosinophil-rich inflammatory infiltrate is found in blister formation. ${ }^{18}$ Eosinophils are a source of tissue factor (TF), which is the initiator of blood coagulation. TF hypercoagulability may contribute to inflammation, tissue damage and later on formation of bullae in BP patients. ${ }^{5}$ Several autoimmune disorders and some inflammatory dermatoses, such as lichen planus and psoriasis, have been reported in patients with BP, leading to the suspicion that the inflammatory process at the dermoepidermal junction in these diseases triggers autoimmunity against the target antigens of BP. ${ }^{18}$

In BP, several cytokines such as IL- $1 \alpha$, IL-1 $\beta$, IL-2, IL-5, IL-6, TNF- $\alpha$ and IFN- $\gamma$ have been observed in blisters or serum. ${ }^{19}$

Since the inflammatory process has been described in BP, cheap and practical markers are needed. NLR may be marker for inflammation in several diseases such as ankylosing spondylitis, familial Mediterranean fever, atherosclerosis, diabetes, malignancies, psoriasis and Behçet disease. ${ }^{20-}$

In the study of Uçmak et al., NLR values in patients with pemphigus vulgaris were significantly higher than that of the control group. ${ }^{23}$ In the study of Ozer et al., patients with bullous pemphigoid, neutrophil count and NLR were found to be significantly higher in BP patients when compared to the controls. ${ }^{10}$ In our study, NLR was found to be higher in BP patients when compared to the age and gender matched control patients. The result in our study may lead to the consideration that NLR might be a practical and cheap indicator of inflammation in BP.

MPV levels have been studied in several diseases, which included skin disorders, such as pemphigus vulgaris, psoriasis, Behçet's disease, and there are conflicting results in these studies. ${ }^{24-26}$ In the study of Rifaioglu et al., MPV value in patients with BP was significantly higher than that of control subjects, but there was no association with disease severity and there was no significant difference between the MPV levels before and after the treatment. ${ }^{9}$ In the study of Ozer et al.,there was no difference in MPV value between the patients with BP and the control group. ${ }^{10}$ In our study, MPV levels were higher in the control group, but there was no significant difference between the two groups. This result suggests that MPV may not be a reliable indicator of inflammation in BP. PLR levels were found to be significantly higher in patients with atopic dermatitis, ${ }^{27}$ psoriatic arthritis, ${ }^{28}$ systemic lupus erythematosus. ${ }^{29}$ In the study of Hayta et al. ${ }^{30}$, there was no difference in patients with pemphigus vulgaris and healthy controls in terms of PLR value. To our knowledge, there is no study investigating PLR value in patients with BP. In our study, there was no difference in PLR between the groups. In our study, the nonsignificant MPV and PLR levels in BP may be due to the comorbid diseases, which can frequently be accompanied by $\mathrm{BP}$ and can effect these values, were not excluded from the study in both patient and control groups.

Limitations of our study were the small number of patients, the fact that the measured markers were not repeated after treatment, the lack of autoimmune bullous skin disorder intensity score and the presence of patients with cardiovascular disorders and diabetes mellitus in the patient group. Systemic inflammatory diseases may alter inflammatory markers independent from bullous pemphigoid.

\section{CONCLUSION}

In conclusion, NLR may be an inexpensive and simple parameter of inflammation in patients with BP as stated in many studies. Our study is the first to evaluate three different inflammation markers such as NLR, MPV and PLR, easily obtained from full blood counts, together in BP patients which is a disease with inflammatory attributes. The results reported here need to be confirmed from long-term studies with larger patient groups. 


\section{REFERENCES}

1. Furue M, Kadono T. Bullous pemphigoid: What's ahead? J Dermatol. 2016 ;43:237-40.

2. Kershenovich R, Hodak E, Mimouni D. Diagnosis and classification of pemphigus and bullous pemphigoid. Autoimmun Rev. 2014;13:477-81.

3. Akay BN, Bodamyalı P, Şanlı H, Akyol A. 10Year Observation of Bullous Pemphigoid Patients. Turkderm 2010; 44: 61-4.

4. Schmidt E, Zillikens D. Pemphigoid diseases. Lancet. 2013;381:320-32.

5. Marzano AV, Tedeschi A, Fanoni D, et al. Activation of blood coagulation in bullous pemphigoid: role of eosinophils, and local and systemic implications. $\mathrm{Br} \mathrm{J}$ Dermatol. 2009;160:266-72.

6. Bancroft AJ, Abel EW, Mclaren M, Belch JJ. Mean platelet volume is a useful parameter: a reproducible routine method using a modified Coulter thrombocytometer. Platelets. 2000;11:379-87.

7. Park Y, Schoene N, Harris W. Mean platelet volume as an indicator of platelet activation: methodological issues. Platelets 2002; 13: 301306.

8. Polat M, Bugdayci G, Kaya H, Oğuzman H. Evaluation of neutrophil-to-lymphocyte ratio and platelet-to lymphocyte ratio in Turkish patients with chronic plaque psoriasis. Acta Dermatovenerol Alp Pannonica Adriat. 2017;26: 97-100.

9. Rifaioglu EN, Sen BB, Ekiz Ö, Dogramaci AC. Mean platelet volume and eosinophilia relationship in patients with bullous pemphigoid. Platelets.2014;25:264-7.

10. Ozer I, Balevi S, Ataseven A. Can Neutrophil/Lymphocyte Ratio Be Used As a Marker in the Diagnosis of Bullous Pemphigoid? Selcuk Med J 2018;34: 65-69.

11. Baum S, Sakka N, Artsi O, Trau H, Barzilai A. Diagnosis and classification of autoimmune blistering diseases. Autoimmun Rev 2014;13:4829.

12. Ekiz Ö, Şen BB, Rifaioğlu EN, et al. Threeyear observation of the patients with bullous pemphigoid: 29 cases. Turkderm 2013;47:205-8.

13. Yazıcı S, Başkan EB, Tunalı Ş, Aydoğan K, Sarıcaoğlu H. Kliniğimizde takip edilen kırk-altı büllöz pemfigoid olgusunun retrospektif analizi.Turkderm 2016;50:114-8.

14. Tan SK, Tay YK. Bullous pemphigoid: Profile and outcome in a series of 100 cases in Singapore. J Dermatol Dermatol Surg 2018;22:12-5.

15. Kizılyel O, Elmas ÖF, Bilen H, et al. Bullous pemphigoid in Erzurum: A 10 year retrospective study. Turkderm 2015; 49: 66-9.

16. Ong E, Goldacre R, Hoang U, Sinclair R, Goldacre M. Associations between bullous pemphigoid and primary malignant cancers: an English national record linkage study, 1999-2011. Arch Dermatol Res 2014;306:75-80.

17. Marzano AV, Tedeschi A, Spinelli D, et al. Coagulation activation in autoimmune bullous diseases. Clin Exp Immunol. 2009;158:31-6.

18. Schmidt E, Della Torre R, Borradori L. Clinical features and practical diagnosis of bullous pemphigoid. Dermatol Clin 2011;29:427-38.

19. Ameglio F, D'Auria L, Bonifati C, et al. Cytokine pattern in blister fluid and serum of patients with bullous pemphigoid: Relationships with disease intensity. $\mathrm{Br} \quad \mathrm{J}$ Dermatol 1998;138:611-4.

20. Gökmen F, Akbal A, Reşorlu $\mathrm{H}$, et al. Neutrophil-Lymphocyte Ratio Connected to Treatment Options and Inflammation Markers of Ankylosing Spondylitis. J Clin Lab Anal. 2015;29:294-8.

21. Sen BB, Rifaioglu EN, Ekiz O, et al. Neutrophil to lymphocyte ratio as a measure of systemic inflammation in psoriasis. Cutan Ocul Toxicol.2014;33:223-7.

22. Ozturk C, Balta S, Balta I, et al. Neutrophillymphocyte ratio and carotid-intima media thickness in patients with Behçet disease without cardiovascular involvement. Angiology. 2015;66:291-6.

23. Uçmak D, Akkurt M, Uçak H, et al. The relationship of neutrophil to lymphocyte ratio with pemphigus vulgaris. Konuralp Medical Journal 2015;2015:88-92.

24. Kridin K, Shihade W, Zelber-Sagi S. Mean Platelet Volume in Pemphigus Vulgaris. Angiology. 2018;69:303-307.

25. Canpolat F, Akpinar H, Eskioğlu F. Mean platelet volume in psoriasis and psoriatic arthritis. Clin Rheumatol. 2010;29:325-8.

26. Balkarli A, Kucuk A, Babur H, Erbasan F. Neutrophil/lymphocyte ratio and mean platelet 
volume in Behçet's disease. Eur Rev Med Pharmacol Sci. 2016;20:3045-50.

27. Jiang Y, Ma W. Assessment of Neutrophil-toLymphocyte Ratio and Platelet-to-Lymphocyte Ratio in Atopic Dermatitis Patients. Med Sci Monit. 2017;23:1340-1346.

28. Kim DS, Shin D, Lee MS, et al. Assessments of neutrophil to lymphocyte ratio and platelet to lymphocyte ratio in Korean patients with psoriasis vulgaris and psoriatic arthritis. J Dermatol. 2016;43:305-10.

29. Wu Y, Chen Y, Yang X, Chen L, Yang Y. Neutrophil-to-lymphocyte ratio (NLR) and platelet-to-lymphocyte ratio (PLR) were associated with disease activity in patients with systemic lupus erythematosus. Int Immunopharmacol. 2016;36:94-99.
30. Hayta SB, Güner R, Akyol M. Blood mean platelet volume may be predictive for disease course in the cases with pemphigus vulgaris. Biomedical Research 2017;28: 4223-4227. 